\title{
HIPÓTESE GAIA E A GRANDE CORRENTE DA VIDA: O ENCONTRO DOS DIREITOS HUMANOS COM A BIODIVERSIDADE GLOBAL NO PARADIGMA DA EQUIDADE
}

\author{
Ana Carolina Vieira de Barros* \\ Lívia Gaigher Bósio Campello**
}

\section{RESUMO:}

A questão da proteção da biodiversidade global é observada como um dos pontos chave para o desenvolvimento sustentável e progresso dos seres humanos. Ao aliar a salvaguarda desses organismos com o crescimento econômico, um novo panorama se solidifica. Esse trabalho debate como a perda gradual dos organismos está afetando o homem, bem como explicita as legislações internacionais que protegem a biodiversidade. Aborda ainda a ideia de sustentabilidade e sua relação com os valores da equidade, responsabilidade e solidariedade intergeracionais. Utiliza-se a pesquisa documental e bibliográfica, a partir do método dedutivo, partindo-se de conceitos genéricos e buscando-se sua afirmação e particularização.

Palavras-chave: Direito Internacional. Direitos Humanos. Direito Ambiental. Biodiversidade. Equidade intergeracional.

\section{GAIA HYPOTHESIS AND THE GREAT CURRENT OF LIFE: ANALISYS OF HUMAN RIGHTS AND THE GLOBAL BIODIVERSITY UNDER THE PARADIGM OF EQUITY}

\begin{abstract}
:
The issue of protecting global biodiversity is seen as one of the key points for sustainable development and progress of human beings. By combining the safeguarding of these organisms with economic growth, a new panorama solidifies. This work discusses how the gradual loss of organisms is affecting man, as well as explaining international legislations that protect biodiversity. It also discusses the idea of sustainability and its relationship with the values of equity, responsibility and intergenerational solidarity. It is used a documental and bibliographic research, from the deductive method, starting from generic concepts and seeking their affirmation and particularization.
\end{abstract}

Keywords: International Law. Human Rights. Environmental Law. Biodiversity. Intergenerational Equity.

\footnotetext{
* Mestranda em Direito pela Fundação Universidade Federal de Mato Grosso do Sul - UFMS. Graduada em Direito pela Fundação Universidade Federal de Mato Grosso do Sul - UFMS. Membro do Grupo de Pesquisa "Direitos Humanos, Meio Ambiente e Desenvolvimento Sustentável Global" (CNPq). Analista Judiciário do Tribunal de Justiça de Mato Grosso do Sul. Endereço eletrônico: anacarolinavb@ hotmail.com.

** Pós-Doutorado em Direito do Estado pela Universidade de São Paulo - USP, Doutorado em Direito das Relações Econômicas e Internacionais pela Pontifícia Universidade Católica de São Paulo - PUC/SP e Mestrado em Políticas Públicas e Processo pelo Centro Universitário Fluminense - UNIFLU. Professora adjunta da Faculdade de Direito na Universidade Federal de Mato Grosso do Sul (UFMS). Coordenadora do Programa de Mestrado em Direitos Humanos da UFMS. Coordenadora do Projeto de Pesquisa "Cooperação Internacional e Meio Ambiente" (MS/FUNDECT). Líder do Grupo de Pesquisa "Direitos Humanos, Meio Ambiente e Desenvolvimento Sustentável Global" (CNPq). Editora-chefe da Revista Direito UFMS. Endereço eletrônico: livia.campello@ufms.br.
} 


\section{INTRODUÇÃO}

A questão da proteção da biodiversidade global é um dos pontos chave para o desenvolvimento sustentável da Terra e progresso dos seres humanos. A importância é tanta que a Assembleia da Organização das Nações Unidas para o Meio Ambiente, ocorrida em Nairóbi, no período de 11 a 15 de março de 2019, ressaltou o alarmante estado do planeta, tendo designado, por meio da Resolução n. $.^{\circ} 73 / 284$, a Década das Nações Unidas para a Restauração dos Ecossistemas - 2021/2030 - (UNEP, 2019).

Apesar da abrangente discussão quanto a esfera da biodiversidade, remanescem questionamentos sobre a perda dessa riqueza e suas consequências diretas ao desenvolvimento econômico dos países, a proteção dos direitos humanos e a capacidade de preservação dos recursos para a utilização das presentes e futuras gerações.

Nesse contexto, este trabalho pretende abordar a inclusão da biodiversidade como um dos critérios do desenvolvimento sustentável, bem como explorar aspectos conceituais, legais e internacionais do assunto. É momento de relacionar a salvaguarda das espécies e do patrimônio genético com o progresso humano, de modo a promover a educação ambiental na sociedade para que o panorama atual seja revertido em favor do meio ambiente.

Ademais, é hora de encarar a finitude das riquezas naturais como resultado do manuseio indevido desses recursos. Essa problemática esbarra em indagações quanto a efetiva equidade e a responsabilidade entre as gerações para manutenção da vida na biosfera, fato que justifica a preocupação das Organizações das Nações Unidas (ONU) em relação a restauração do meio ambiente.

Como referido no documento gerado em sessão realizada no supramencionado encontro global, a ONU reconhece que tanto as soluções sustentáveis e inovadoras quanto a preservação dos ecossistemas para a diminuição da perda de biodiversidade e da degradação da terra refletem a necessidade de aumentar a capacidade da natureza para continuar a fornecer esses benefícios aos seres humanos (UNEP, 2019).

Desse modo, é difundido o desafio de um novo modelo de desenvolvimento econômico, fundado na renovação cíclica das riquezas e na construção de um panorama relacionado ao consumo consciente, sob o prisma da solidariedade e ajuda mútua entre as 
nações. Assim, a biodiversidade se traduz em uma das principais aliadas da sociedade, especialmente para que esse almejado cenário se torne realidade e se faça presente a esperança quanto a continuidade e fluidez da corrente da vida.

\section{A ERA DO DESENVOLVIMENTO SUSTENTÁVEL EM UMA PERSPECTIVA MUTÁVEL}

O termo desenvolvimento sustentável, criado pela Comissão Mundial sobre Meio Ambiente e Desenvolvimento, estabelecida pela ONU, é comumente apontado pela sociedade nos dias atuais. As pessoas fazem referência a esse conceito como modo de vivência relacionado a harmonia entre o progresso econômico e a conservação ambiental, ou seja, o uso racional dos recursos naturais no presente a fim de que não haja esgotamento posterior que possa comprometer as gerações futuras, assim como definido no Relatório Brundtland:

Acreditando que o desenvolvimento sustentável, que implica satisfazer a necessidade do presente sem comprometer a capacidade do futuro gerações para atender suas próprias necessidades, deve tornar-se um princípio orientador central da ONU, dos governos e instituições privadas, organizações e empresas (ONU, 1987).

Outrossim, torna-se imperioso relacionar que o conceito em destaque possui, pelo menos, quatro acepções correlatas: a paz e a segurança, o desenvolvimento econômico, o desenvolvimento social e a capacidade de os governos nacionais assegurarem a paz e o crescimento global (SHIM, 2003, p. 179).

Posto isso, compreende-se que as definições acima explicitadas são fruto de uma abstração contínua da temática. A abordagem em comento necessita ser revista e aprimorada com o passar do tempo, tendo em vista que as relações sociais e econômicas sofrem alterações conforme o estilo de vida do homem vai se modificando. Destarte:

Passa a fluir como natural que a ordem não mais seja dada como algo estabelecido e tutelado, mesmo a partir da estrutura cultural e social. A ordem no moderno será a conquista possível do consenso viável entre pares e diversos. Por isso mesmo ela será, não raro, precária e instável, sujeita sempre a renegociações e definições (MARÇOLLA, 2017).

Nesse cenário, o desenvolvimento passa a englobar uma visão holística quanto ao envolvimento cada vez maior do ser humano com o meio ambiente. Por essa visão, homens e 
mulheres percebem a natureza como um todo do qual fazem parte, refletindo que o meio ecologicamente equilibrado é direito de todos os seres.

Prova dessa visão mutável pode ser visualizada na prática, por meio da nota conceitual proposta em El Salvador, com o apoio dos países do Sistema de Integração da América Central, vez que esse debate foi essencial para o estabelecimento da Década das Nações Unidas para Restauração dos Ecossistemas:

A comunidade global tem de frear a sua ambição a fim de restabelecer todos os ecossistemas, incluindo florestas, pastagens, terrenos, zonas úmidas, savanas e outros ecossistemas terrestres e de águas continentais, ecossistemas marinhos e costeiros e, caso seja preciso, ambientes urbanos. Renovado vigor e compromisso são necessários para alcançar a restauração do ecossistema. O engajamento, os esforços e as ações dos países, da comunidade internacional, da sociedade civil, do setor privado e de outros atores precisam ser reavaliados e revisionados de forma conjunta. Isto permitirá abordar de forma holística as interdependências dos ecossistemas, das necessidades humanas e da biodiversidade através de uma abordagem paisagística da restauração dos ecossistemas, desencadeando progressos acelerados no ritmo e na escala necessários para manter e restabelecer ecossistemas, trazendo um maior equilíbrio entre o bem-estar social, a vida na terra e o crescimento econômico sustentável (EL SALVADOR INICIATIVE, 2019).

Além disso, é de suma importância observar que os avanços tecnológicos envolvendo questões atinentes à biodiversidade, como a chegada da biotecnologia, impactam o desenvolvimento sustentável, que deve ser analisado e redimensionado nesse contexto de avanço da tecnologia e sua possível influência negativa na natureza. Assim:

A proteção da diversidade biológica é outra questão ambiental em torno da biotecnologia [...] concluindo, a definição geral de desenvolvimento sustentável, na medida em que o direito internacional reconhece o conceito de desenvolvimento sustentável, deve, principalmente, aprovar os seguintes interesses: a - a necessidade de levar em consideração as necessidades de gerações presentes e futuras; $b$ - a aceitação, por razões de proteção ambiental, dos limites colocados na utilização e na exploração dos recursos naturais; c - o papel dos princípios equitativos na alocação de direitos e obrigações; e, d - a necessidade de integrar todos os aspectos do meio ambiente e do desenvolvimento (SHIM, 2003, p. 166 e 182-183).

Logo, a proteção da biodiversidade adquire uma importância primordial para o desenvolvimento sustentável, visto que atua na manutenção do meio ambiente e, 
consequentemente, contribui para a solidificação do modelo econômico que engloba as necessidades dos seres humanos e da natureza $a^{\dagger \dagger}$.

Para além, com o intuito de aliar esses preceitos à prosperidade das nações, é essencial que a sociedade deixe de lado a visão apenas antropocêntrica sobre a construção do progresso. Dessa forma, considerar os organismos existentes e suas necessidades constitui um passo importante para a renovação dos recursos e continuidade da vivência do modelo econômico atual.

Afinal, com uma diminuição impactante das riquezas ambientais, o estilo de vida dos seres humanos será drasticamente modificado, momento em que as pessoas poderão perder o referencial de sua existência. Uma vez que o padrão criado pelo homem é norteado principalmente pelo consumo desenfreado, o qual é alimentado pela exploração contínua dos recursos. "Assim toda a questão se reduz a isto: pode a mente humana dominar o que a mente humana criou?" (BAUMAN, 2001, p. 7).

A difusão da visão ecocêntrica, fundada na unidade dos organismos e, principalmente, na solidariedade entre espécies, se torna primordial para que novos ideais sejam abarcados pela comunidade e juntos se tornem força motriz para a continuidade da existência. Por isso, na conjuntura global, os atores internacionais se preocupam tanto em solidificar a ideia dessa evolução compartilhada, justamente porque a preocupação se concentra também no que o homem poderá vir a se tornar quando caso os recursos se findem.

De igual maneira, para Torrado (2000, p. 47) os processos de globalização contribuem para que decisões e atividades ocorridas em um lugar do mundo repercutam de forma significativa no outro lado do globo. Como uma rede, as relações econômicas, culturais e sociais se ligam de forma interdependente e cada vez mais os diversos âmbitos da vida são controlados pelo livre mercado, com o ideal neoliberal.

Como consequência "A globalização implica o desaparecimento das antigas certezas, a segurança derivada das referências de identidade e identificação com o ambiente social em

\footnotetext{
†† Entretanto, na esfera da educação ambiental, percebe-se haver certo desconhecimento quanto a importância e os impactos relacionados a perda da biodiversidade global. Consequentemente, em conformidade com o preâmbulo da Convenção sobre Diversidade Ecológica, assinada na Conferência das Nações Unidas sobre Meio Ambiente, ocorrida no Rio de Janeiro/RJ, no ano de 1992, a qual entrou em vigor em território brasileiro no dia 03 de fevereiro de 2004, o desafio é superar a falta de informação sobre a diversidade biológica, a fim de capacitar científica, técnica e institucionalmente, de forma urgente, a sociedade, para que se obtenha o conhecimento para o planejamento e implementação das mudanças necessárias (CONVENÇÃO SOBRE DIVERSIDADE ECOLÓGICA, 2004).
} 
que o sujeito está integrado, a desintegração dos princípios morais e políticos, a fluidez das identidades, o sujeito desinserido" (TORRADO, 2000, p. 53).

A partir disso, vislumbrar o futuro é confrontar o próprio âmago do desenvolvimento humano e lidar, seriamente, com uma possível alteração na gama dos direitos existentes no presente, bem como na ruptura do modelo econômico o qual é hoje conhecido por todos. Com efeito,

Tratar a vida e a qualidade de vida de forma inconsequente é um problema dos modelos econômicos do mercado livre. Desastres ambientais causados pelo desmatamento, depleção de aquíferos e extinção de espécies são, por definição, "externalidades" do mercado e não são considerados na equação primária de desenvolvimento. Os custos desses desastres realmente aumentam os índices macroeconômicos, contribuindo para o grande produto nacional bruto. $\mathrm{Na}$ realidade, deixar de levar em consideração as necessidades das espécies não-humanas pode ser desastroso para seres humanos e é indiscutivelmente a principal causa na geração de refugiados econômicos (ASH, 2007, p. 217).

Desse modo, após observar a mutabilidade do pensamento sustentável e da solidificação da visão biocêntrica que passa a nortear as ações dos seres humanos, inclusive na seara econômica, os aspectos e desafios atinentes à biodiversidade podem adentrar o saber do leitor de maneira significativa, como um alarme para a ação coletiva.

\section{AFINAL, O QUE É BIODIVERSIDADE?}

O pesquisador James Lovelock trouxe, na década de 70, uma arrojada visão sobre o mundo. Em sua obra de renome intitulada "As Eras de Gaia”, o ambientalista, compartilhando dos referenciais de Lynn Margulis, denominou a Gaia, ou seja, a Mãe Terra, como um "superorganismo", que "formado pela superfície da Terra, ar e oceanos, funcionaria como um sistema vivo, capaz de regular a composição atmosférica, a salinidade dos mares e o clima, o que permitiria mantê-lo sempre adequado à vida" (ARAGÃO, 2011). Nesse sentido,

$\mathrm{Na}$ concepção de James Lovelock e Lynn Margulis, a Terra é um superorganismo vivo, que deve ser estudado como um sistema em sua integridade. Essa teoria representa uma forma singular de holismo científico. Isso significa que não somente os organismos vivos podem modificar o ambiente não vivo, mas ambos evoluem juntos ao longo do tempo. Essa é uma concepção inovadora em relação à visão darwinista clássica. Como na natureza todos os seres vivos possuem um nome, Lovelock alcunhou o maior organismo vivo conhecido do Universo de Gaia, em homenagem à deusa grega que representa a Terra (CARVALHO, 2011, p. 25). 
Lovelock prega que para a autorregulação da vida no globo é imprescindível que haja a abundância de espécies: a tão conhecida biodiversidade. Essa integração entre os seres vivos pode ser melhor conceituada a partir da seguinte opinião:

\begin{abstract}
A diversidade biológica ou, como é mais comumente chamada, biodiversidade é a variedade ou a variabilidade entre os organismos vivos, os sistemas ecológicos nos quais se encontram e as maneiras pelas quais interagem entre si e a ecosfera (região da atmosfera onde há seres vivos); pode ser medida em diferentes níveis: genes, espécies, níveis taxonômicos (de classificação) mais altos, comunidade e processos biológicos, ecossistemas, biomas, e em diferentes escalas temporais e especiais. Em seus diferentes níveis, pode ser medida em número ou frequência relativa (TORRES apud SILVA, 2015).
\end{abstract}

A importância dessa diversidade genética reside, principalmente, na sobrevivência e possibilidade da evolução das espécies. É impactante e de certa forma perigoso que o ser humano, como gestor da vida na Terra, acabe dizimando essa vital diferença entre os organismos. Conforme preconiza Young-Gyoo Shim "da perspectiva da diversidade genética no homem, a biodiversidade é provavelmente apresentada como um ideal para garantir mais liberdade para os seres humanos" (SHIM, 2003, p. 200).

Além disso, a existência dos ecossistemas deve-se à biodiversidade em vários níveis. Não há como múltiplos biomas perpetuarem entre as gerações se não houver, de algum modo, interdependência entre as espécies para a conservação do solo, ar atmosférico, bacias hídricas e diversos outros fatores. A autorregulação proposta por Lovelock é real, ela se chama Terra.

Pelo viés econômico, a variedade da natureza é base para os estudos humanos a fim de que haja melhoria na utilização de recursos terrestres, cura de doenças, implemento de alimentos, entre outros. Por conseguinte, visualiza-se:

A biodiversidade é também de grande importância - econômica, médica, etc. - para o ser humano. Diversas plantas possuem princípios ativos utilizados na indústria farmacêutica, como o salgueiro-branco (Salix alba), que possui o ácido salicílico - composto de onde é derivado o ácido acetilsalicílico, a aspirina. Substâncias chamadas alcaloides, como a cafeína e a nicotina também estão presentes, respectivamente, em plantas como o cafeeiro (Coffea sp.) e o tabaco (Nicotiana sp.) Dentre espécies de animais, podemos citar o gado (Bos taurus) e galinha (Gallus gallus domesticus) domésticos, utilizados na alimentação humana (MOIA, 2016).

Ocorre que o homem ao perceber o potencial que a biodiversidade carrega em si, a transforma em alavanca para o crescimento econômico. Entretanto, a ambição que a 
sociedade carrega consigo faz com que essa diversidade seja visualizada no limite entre propriedade ou recurso.

É nesse contexto que a comunidade internacional passa a se movimentar com vistas a assegurar que essa riqueza seja utilizada conscientemente. Desse modo, nascem as convenções e tratados internacionais sobre o assunto.

Em 1948, foi criada a União Internacional para a Conservação da Natureza e dos seus Recursos (IUCN), "Como se pode notar, o espectro de atuação da IUCN é amplo e além do debate frequente das questões naturais, a organização também se torna base intelectual para diversos movimentos e, principalmente, para as políticas estatais e ações adotadas por grupos da sociedade civil" (CAMPELLO; BARROS, 2018, p. 98).

Interessante, ressaltar, em sequência, que o ano de 1948 deu origem a Convenção Internacional para a Regulação da Atividade Baleeira, a fim de afastar a exploração das baleias, especialmente a caça comercial, a qual foi banida em 1986, como medida de proteção contra a extinção do animal. É triste lembrar que o Japão deixou de aderir ao pacto em 2018 e passa a realizar, além da caça científica (não proibida), aquela para eles retratada como "uso sustentável" e parte da cultura japonesa. Em continuação:

Adiante, em 1973 foi estabelecida a Convenção sobre Comércio Internacional das Espécies da Flora e Fauna Selvagens em Perigo de Extinção (CITES), assinada hoje por 183 (cento e oitenta e três) países, a qual foi elaborada "para regular de forma eficaz o comércio de espécies da fauna e flora, prevenindo-as do perigo de extinção, quando a ameaça for o comércio internacional" (BARROS; CAMPELLO, 2018, p. 99).

Anos seguintes, após o Relatório Brundtland ou "Nosso Futuro Comum" como é conhecido o documento que inaugurou, em aspecto global, no ano de 1987, o conceito de desenvolvimento sustentável, os debates acerca da capacidade dos ecossistemas se intensificaram. Em seguida, a Conferência das Nações Unidas sobre Meio Ambiente e Desenvolvimento (CNUMAD), a Rio-92, foi palco do estabelecimento de um dos documentos mais relevantes para a garantia das espécies: a Convenção sobre a Diversidade Biológica (CBD).

O referido acordo se traduz em um verdadeiro guia para a sustentabilidade dos recursos, colecionando 168 (cento e sessenta e oito) assinaturas até a presente data:

A Convenção está estruturada sobre três bases principais - a conservação da diversidade biológica, o uso sustentável da biodiversidade e a repartição justa e equitativa dos benefícios provenientes da utilização dos recursos genéticos - e se refere à biodiversidade em três níveis: ecossistemas, espécies e recursos genéticos. 
A Convenção abarca tudo o que se refere direta ou indiretamente à biodiversidade - e ela funciona, assim, como uma espécie de arcabouço legal e político para diversas outras convenções e acordos ambientais mais específicos, como o Protocolo de Cartagena sobre Biossegurança; o Tratado Internacional sobre Recursos Fitogenéticos para a Alimentação e a Agricultura; as Diretrizes de Bonn; as Diretrizes para o Turismo Sustentável e a Biodiversidade; os Princípios de Addis Abeba para a Utilização Sustentável da Biodiversidade; as Diretrizes para a Prevenção, Controle e Erradicação das Espécies Exóticas Invasoras; e os Princípios e Diretrizes da Abordagem Ecossistêmica para a Gestão da Biodiversidade. A Convenção também deu início à negociação de um Regime Internacional sobre Acesso aos Recursos Genéticos e Repartição dos Benefícios resultantes desse acesso; estabeleceu programas de trabalho temáticos; e levou a diversas iniciativas transversais (MMA, 2019).

Imprescindível destacar que a Convenção aborda acordos suplementares que auxiliam e asseguram a biodiversidade global. Entre eles pode-se frisar o Protocolo de Cartagena sobre Biossegurança, o qual confere a proteção para transferência, manipulação e uso dos organismos vivos modificados advindos da biotecnologia. Nessa mesma esteira, o Tratado Internacional sobre Recursos Fitogenéticos para a Alimentação e a Agricultura objetiva "a conservação e o uso sustentável dos recursos fitotogenéticos para a alimentação e a agricultura e a repartição justa e equitativa dos benefícios derivados de sua utilização, em harmonia com a CDB, em prol de uma agricultura sustentável e da segurança alimentar" (MAPA, 2018). De igual maneira, as Diretrizes de Bonn observam as questões atinentes à gestão de acesso e repartição dos recursos genéticos entre os países.

Posteriormente, mas não menos importante, há outros princípios e diretrizes utilizados para atingir os demais objetivos da Convenção. São eles: as Diretrizes para o Turismo Sustentável e a Biodiversidade (integração sustentável entre o turismo e os ecossistemas); os Princípios de Addis Abeba para a Utilização Sustentável da Biodiversidade (apresenta as ligações entre o uso dos recursos naturais e a manutenção de culturas, sociedades e comunidades); as Diretrizes para a Prevenção, Controle e Erradicação das Espécies Exóticas Invasoras (gestão das interações entre os organismos); e os Princípios e Diretrizes da Abordagem Ecossistêmica para a Gestão da Biodiversidade (plano de ação em relação as questões que circundam o tema).

Portanto, a análise legislativa internacional colecionada só demonstra de forma acentuada o quanto o assunto repercute na vida em comunidade. Para além, a biodiversidade global se encontra em alerta para proteção e, principalmente, deve se reconhecer que ela traduz ganho econômico e possibilidade de progresso. 
Apesar dos inúmeros benefícios, o conceito em destaque traz desafios, entre eles as experiências advindas da biotecnologia, considerando que as consequências podem ser desastrosas. Como prova disso citam-se os produtos desenvolvidos e comercializados pela empresa Monsanto, como o poliestireno (gera efeitos em humanos e, principalmente, no meio ambiente ante a não decomposição do plástico); pesticidas em geral (como dioxina, agente laranja e DDT) - promovem o envenenamento de animais que possam vir a se alimentar das plantações; e, os hormônios para crescimento bovino (causa enfermidades nos animais e em humanos que consomem os produtos).

Em seguida, considerável frisar que além da situação de degradação ambiental e perda real da biodiversidade, a humanidade reflete conceitos éticos quanto ao manejo do patrimônio genético. Recentemente, o nascimento dos bebês geneticamente modificados por um cientista chinês impactou a comunidade internacional e a fez analisar os limites quanto ao uso da biotecnologia.

Sobre o assunto, se faz relevante destacar:

Em conclusão, a revolução da biotecnologia moderna instrui que os recursos vivos, incluindo os recursos biológicos ou genéticos, bem como os recursos não-vivos, podem ser esgotáveis, e que a biotecnologia moderna pode promover ou destruir o desenvolvimento sustentável desses materiais biológicos. Em particular, de acordo com as características evolutivas da biotecnologia moderna, será mais razoável que os recursos biológicos e genéticos, incluindo os recursos genéticos humanos, sejam tratados dentro de uma categoria de recursos naturais esgotáveis, a serem protegidos para promover o desenvolvimento sustentável (SHIM, 2003, p. 202).

Como resultado, observa-se que a utilização dos recursos naturais pode trazer tanto benefícios quanto malefícios. O bom uso resulta de um estudo contínuo sobre os organismos que alie a produção de bens com a defesa dos ecossistemas, bem como ao fato de que se deve atentar aos avanços da biotecnologia, de modo que se possa buscar diretrizes legais capazes de prezar pelo bem estar dos seres vivos.

Após a abordagem do contexto e dos desafios que envolvem a biodiversidade é que se pode visualizar os pontos desse estudo sob o prisma do paradigma da equidade. Em vista disso, essa visão poderá ser utilizada como forma de reflexão e solução para questões que envolvem o uso do meio ambiente.

\section{EQUIDADE, RESPONSABILIDADE E SOLIDARIEDADE INTERGERACIONAIS: CAMINHO PARA O FUTURO}


A partir de conceitos filosóficos, a equidade correlaciona-se "com a própria noção de justiça, aquilo que Aristóteles identificou como dar a cada um o que é seu, a distribuição correta e razoável de direitos, garantias e oportunidades" (BRANDÃO; SOUZA, 2010, p. 165)

A teoria da equidade intergeracional foi cunhada pela jurista Edith Brown Weiss, em um universo em que o Direito Internacional se torna peça chave para a salvaguarda de obrigações e direitos planetários que possam resguardar a Terra para as futuras gerações. Afinal, semelhante a série científica "The OA" de Brit Marling e Zal Batmanglij, do canal de streaming Netflix, na qual as dimensões se conectam, podendo gerar consequências umas nas outras, o ser humano compartilha o planeta com a geração em que se encontra e as outras que estão por vir e isso não é mais obra de ficção. Explica-se:

Edith Brown Weiss, professora de Direito no Georgetown University Law Center, Estados Unidos, concebeu a teoria da equidade intergeracional, na esfera do Direito Internacional. Aplicada aos patrimônios natural e cultural, a teoria assume que cada geração recebe o planeta em fideicomisso para as futuras gerações. Isso implica, simultaneamente, a existência de certos direitos planetários para uso desse patrimônio e a imposição de certas obrigações planetárias sobre cada geração, no sentido de conservar a qualidade e diversidade dos recursos naturais e culturais para as futuras gerações (CARVALHO, 2011, p. 450).

Nessa esteira, a jurista assinala alguns problemas que mais afetam as gerações. A mudança climática, o derretimento das geleiras, o aumento dos resíduos sólidos e as dificuldades para o seu devido descarte são algumas das questões enfrentadas. Entretanto, países já desenvolvidos lidam com essa problemática diferentemente das nações em desenvolvimento, até porque o manejo dos recursos é diferente para ambos, fato que interfere na teoria apresentada por Weiss quanto à repartição dos frutos do patrimônio comum entre os países da geração atual (CARVALHO, 2011, p. 451). Portanto, a equidade preocupa-se, ademais, em como essa desigualdade afeta a solidificação de um ideal planetário: "significa uma partilha justa e equitativa dos benefícios entre os países em desenvolvimento com recursos genéticos ricos e países desenvolvidos que exploram e patenteiam os materiais genéticos dos países em desenvolvimento" (SHIM, 2003, p. 168).

De igual modo:

O problema mais urgente, hoje, em termos de equidade, resulta das desigualdades econômicas e sociais, entre e dentro dos países, e daí resulta a 
indagação: Como se pode esperar que uma comunidade empobrecida possa cuidar das gerações futuras se ela não pode cuidar de seus contemporâneos? Para solucionar esse problema, basta pôr em prática a recomendação da Declaração do Rio, insculpida no princípio $5^{\circ}$, segundo a qual, todos os Estados e indivíduos têm, como requisito indispensável ao desenvolvimento sustentável, o dever de cooperar na tarefa essencial de erradicar a pobreza, de forma a reduzir as disparidades nos padrões de vida e melhor atender às necessidades da maioria da população do mundo (CARVALHO, 2011, p. 452).

Por essa razão, é essencial assinalar que existe uma diferença de proteção para alcance da equidade intrageracional, ou seja, entre as múltiplas realidades que compõem o globo nos dias atuais, e da equidade intergeracional a qual é reforçada pela preocupação com o futuro daqueles que ainda farão parte do planeta. Em suma, a equidade intergeracional pressupõe a intrageracional.

Para Weiss, a equidade intergeracional possui princípios que norteiam a sua ação. São eles: o Princípio da Conservação das Opções, na qual as pessoas na atualidade devem se preocupar em fornecer aos que chegarão a base de recursos naturais e culturais a qual tiveram acesso, de modo a não restringir as opções, valores e vivência das populações futuras; o Princípio da Conservação da Qualidade, que veda o repasse do planeta em condições piores do que as que se teve acesso; e, o Princípio da Conservação do Acesso, referente à passagem dos direitos equitativos de acesso (CARVALHO, 2011, p. 454).

Posto isso, há as seguintes obrigações intergeracionais:

Conservar os recursos de forma a manter suficiente diversidade para preservar as opções futuras; b) assegurar a todas gerações acesso equitativo aos recursos; c) evitar impactos adversos pelas presentes ações, de modo a transmitir o planeta em tão boas condições como as em que foi recebido; d) prevenir desastres, minimizar danos e providenciar assistência emergencial; e) recompor e compensar os danos ambientais (CARVALHO, 2011, p. 455).

Em contraposição a teoria de Weiss, na qual os direitos planetários pertenceriam a uma coletividade, em caráter difuso, há a vertente defendida por Beckerman e Pasek, pela qual há uma abordagem de concentração dos esforços nas gerações presentes, sendo estas as únicas com potencial para mudança (CARVALHO, 2011, p. 456).

Dentro desse espectro de teorias, a responsabilidade entre as gerações é tão visível que 1997 foi o ano da Declaração sobre as Responsabilidades das Gerações Presentes em Relação às Gerações Futuras. Esse documento abarcou muitos dos conceitos abordados por Weiss em busca da preservação da humanidade, com respeito a dignidade do homem, ao meio 
ambiente, ao patrimônio genético e a biodiversidade. Evidencia-se, similarmente, que o Princípio da Responsabilidade entre as gerações baseia-se nas acepções contidas no Relatório Brundtland, sendo confirmado, posteriormente na Rio-92 e na Agenda 21.

Desse modo, como consagra a declaração "O progresso científico e tecnológico não deve, de forma alguma, prejudicar ou comprometer a preservação da espécie humana e de outras espécies" (UNESCO, 1997). Para isso, a equidade e responsabilidade inter e intragernacional passa pela utilização da biodiversidade de forma consciente, não desgastada pelo valor do consumo desenfreado e tampouco pelo manuseio da biotecnologia em favor das necessidades econômicas de certas nações.

Quanto ao manuseio das tecnologias volta-se a mencionar que a Convenção sobre a Biodiversidade Ecológica e seus acordos, tratados, diretrizes e princípios suplementares pretendem servir como base para o uso das ferramentas ligadas à biotecnologia. Como exemplo destacam-se as Diretrizes de Bonn, adotadas pela Conferência das Partes da Convenção Sobre Diversidade Biológica, em 2002, na cidade de Bonn, na Alemanha, fundamentadas no acesso e repartição igualitária dos benefícios advindos dos recursos genéticos para orientar a ação de governos e instituições privadas.

Por fim, é nesse diapasão que a cooperação global entra em cena e se torna a principal ferramenta para mudança de realidade. É a ajuda mútua internacional que será a responsável por estabelecer uma nova ordem social e ambiental. É aí que a equidade e a responsabilidade entre as gerações se deparam com o ideal que as complementa: a solidariedade inter e intrageracional. Ou seja:

Então, tem-se que o conceito de solidariedade é inovador ao estabelecer uma relação de reciprocidade, que se relaciona com os conceitos de equidade e igualdade, formando uma relação horizontalizada, substituindo a relação doador-receptor e dando lugar à relação doador-receptor e receptor-doador, no sentido de compartilhamento mútuo, o mesmo ente ou indivíduo pode ser doador em uma situação e receptor em outra (REIS; CAMPELLO, 2018, p. 129).

Posto isso, a cooperação reside em uma importante aliada para a implementação das ações que cercam o desenvolvimento sustentável. Quando uma nação compartilha de seus recursos técnicos e científicos com as demais, se torna mais fácil dirimir os desafios enfrentados por cada uma internamente e solidificar uma rede de desenvolvimento conjunto.

Nessa linha de pensamento, a cooperação pode auxiliar na minimização dos impactos ambientais, à medida que as ações de cada país forem analisadas e os mesmos se 
comprometerem a cumprirem as ações pactuadas por meio de tratados, convenções e acordos internacionais.

Portanto, falar sobre biodiversidade é discorrer hoje sobre o desenvolvimento sustentável em uma perspectiva de equidade. Não se pode pensar que o progresso econômico e social virão sem que os recursos naturais sejam utilizados, mas é importante implementar no presente a integração dessas características como valores a serem perpetuados na sociedade objetivando a construção de uma identidade entre o homem e o ambiente ao seu entorno.

Igualmente, a existência de parâmetros que norteiem a humanidade, como a equidade, a responsabilidade e a solidariedade intergeracionais contribuem para o fomento de legislações sobre o tema e de modelos de gestão a serem seguidos pelas nações. Só assim uma melhor distribuição de recursos naturais e genéticos pode ser alcançada, de modo a solidificar a igualdade de acesso aos bens da natureza e a tecnologia que os envolve.

\section{CONCLUSÃO}

O superorganismo "Gaia", comumente reconhecido como a "Mãe-Terra" possibilita a vida em seus diversos desdobramentos, ou seja, dá à luz a biodiversidade global. Entretanto, a forma como o ser humano lida com a multiplicidade de espécies e recursos deve ser adequada ao desenvolvimento econômico que objetiva, em uma face sustentável.

Nessa linha, o leitor se torna capaz de visualizar que o novo modelo de crescimento que a comunidade internacional e seus diversos atores se colocam à disposição para construir deve ser ponderado ao lado da finitude dos recursos que a natureza provém e da urgente necessidade de mudança que as relações sociais e para com o meio ambiente deverão sofrer a fim de que o amanhã para as futuras gerações seja possível.

Abordar a mutabilidade, em um primeiro momento, quanto à conceituação do termo desenvolvimento sustentável confere a oportunidade àquele que lê o texto de abstrair antigas acepções sobre a temática, confrontando a estabilidade dos significados. A partir disso, aliar a sustentabilidade com as conquistas econômicas, sociais e culturais se torna plausível à medida que o indivíduo passa a constatar que a biodiversidade tem papel fundamental no progresso e que sem ela a grande corrente da vida encontrará obstáculos para fluir.

Pertinente lembrar que a degradação ambiental afeta o ser humano, de modo grave, vez que contribui para a ruptura do ciclo da vida. Entretanto, convém refletir que a perda 
gradual de biodiversidade e desgaste da natureza também acarreta alteração nos Direitos Humanos. Afinal, com a perda das riquezas, não há como tutelar, como direito básico, aquilo que o homem não mais detém.

Em sequência, visualizar a biodiversidade sobre um plano mais prático, com a demonstração de seus benefícios e desafios na realidade, constitui em uma ferramenta de educação ambiental. Vale relembrar que a capacitação e a divulgação do conhecimento técnico e científico da diversidade dos organismos é um dos objetivos assinalados pela Convenção sobre a Biodiversidade Biológica.

De igual modo, o Direito Ambiental e o Direito Internacional reforçam a aliança com os Direitos Humanos a fim de demonstrar que parâmetros como o da Equidade, da Responsabilidade e da Solidariedade Intergeracionais se ligam a sustentabilidade.

Em síntese, a biodiversidade deve ser vista por uma dupla perspectiva: pela sua função biocêntrica que traz equilíbrio ao próprio ecossistema e pela sua utilidade para o homem enquanto recurso ambiental de interesse econômico, principalmente para atender às necessidades básicas humanas, ou seja, aos Direitos Humanos.

\section{REFERÊNCIAS}

ARAGÃO, Maria José. Biodiversidade e Sustentabilidade da Vida. Ed. Média XXI: Coleção Rés Culturas, Educação \& Ciências.1ª Edição. 2011.

ASH, Kyle. Why managing biodiversity will fail: an alternative approach to sustainable explotation for interntional law. Animal Law. Vol. 13. 2007. 41 p.

BAUMAN, Zygmunt. Modernidade líquida. Rio de Janeiro: Jorge Zahar. 2011. 258 p.

BRANDÃO. Luiz Carlos Kopes; SOUZA, Carmo Antônio de. O princípio da equidade intergeracional. Planeta Amazônia: Revista Internacional de Direito Ambiental e Políticas Públicas, n. 02, 2010, p. 163-175.

BRASIL. Decreto n. ${ }^{\circ} 02$ de 03 de fevereiro de 1994. Convenção sobre a Diversidade Biológica. Disponível em: http://www.mma.gov.br/estruturas/sbf_dpg/_arquivos/cdbport.pdf. Acesso em: 25 mar. 2019. 
CAMPELLO, Lívia Gaigher Bósio; REIS, João Henrique Souza dos. Direitos Humanos e os Desafios à Solidariedade Intergeracional no Cenário de Crise Ambiental Global. Revista de Direitos Humanos em Perspectiva, v. 4, n. 2, 2018, p. 124-145.

CAMPELO, Lívia Gaigher Bósio; BARROS, Ana Carolina Vieira de. A Era da Afirmação dos Direitos dos Animais no Cenário Global e seu Fundamento na Solidariedade entre Espécies. Revista Brasileira de Direito Animal, v. 13, n. 02, 2018, p. 95-109.

CARVALHO, Edson Ferreira de. Meio Ambiente \& Direitos Humanos. $2^{\text {a }}$ Edição - Revista e Atualizada, Juruá Editora, 2011.

EL SALVADOR. Concept note. Initiative proposed by El Salvador with the support of countries from the Central American Integration System (SICA). UN Decade of Ecosystem Restoration 2021 - 2030. Disponível em: https://wedocs.unep.org/bitstream/handle/20.500.11822/26027/Ecosystem_decade_Salvador_ Initiative.pdf?sequence=1\&isAllowed=y. Acesso em: 24 mar. 2019.

MARÇOLLA, Bernardo. Psicologia e Ecologia: natureza, subjetividade e sua interseções. 2017.

MINISTÉRIO DA AGRICULTURA, PECUÁRIA E ABASTECIMENTO (MAPA). Tratado Internacional sobre Recursos Fitogenéticos para Alimentação e Agricultura (TIRFAA). Disponível em: http://www.agricultura.gov.br/assuntos/sustentabilidade/tecnologiaagropecuaria/tirfaa. Acesso em: 08 abr. 2019.

MINISTÉRIO DO MEIO AMBIENTE (MMA). Convenção da Diversidade Biológica. Disponível em: http://www.mma.gov.br/biodiversidade/conven\%C3\%A7\%C3\%A3o-dadiversidade-biol\%C3\%B3gica.html. Acesso em: 30 mar. 2019.

MOIA, Igor Wassiljew. Biodiversidade: por que é tão importante? Universo racionalista. Disponível em: https://universoracionalista.org/biodiversidade-importancia-e-definicao/. Acesso em: 25 mar. 2019.

ORGANIZAÇÃO DAS NAÇÕES UNIDAS (ONU). Report of the World Comission on Environment and Development. General Assembly, A/RES/42/1987, 96th Plenary Meeting, 1987. Disponível em: https://www.un.org/documents/ga/res/42/ares42-187.htm. Acesso em: 08 abr. 2019. 
ORGANIZAÇÃO DAS NAÇÕES UNIDAS PARA A EDUCAÇÃO, A CIÊNCIA E A CULTURA (UNESCO). Declaração Sobre as Responsabilidades das Gerações Presentes em Relação as Futuras Gerações, Paris, 1997.

PRESSE, France. Cientista chinês que anunciou bebês geneticamente modificados suspende testes. Disponível em: https://g1.globo.com/ciencia-esaude/noticia/2018/11/28/cientista-chines-que-anunciou-bebes-geneticamente-modificadossuspende-testes.ghtml. Acesso em: 25 mar. 2019.

SECRETARIADO DA CONVENÇÃO SOBRE BIODIVERSIDADE ECOLÓGICA. As Diretrizes de Bonn. Canadá, 2012. Disponível em:

http://www.mma.gov.br/images/publicacoes/patrimonio_genetico/Cartilhas\%20Informativas $\% 20$ sobre\%20ABS\%2005\%20-\%20As\%20Diretrizes\%20de\%20Bonn.pdf. Acesso em: 08 abr. 2019.

SHIM, Young-Gyoo. Intellectual Property Protection of Biotechnology and Sustainable Development in International Law. N.C.J. Int'L \& Com. Reg. Vol: 29. 2003, p. 159-248.

SILVA, Américo Luís Martins da. Direito do Meio Ambiente e dos Recursos Naturais. Volume 1. Impacto ambiental. PNMA. SISNAMA. Licenciamento ambiental. Responsabilidade Ambiental. 2015.

TORRADO, Jesus Lima. Globalización y Derechos Humanos. Anuario de Filosofia del Derecho, n. 17, 2000, p.43-74.

UNITED NATIONS ENVIRONMENT PROGRAMME (UNEP). United Nations Environment Assembly of the United Nations Environment Programme, Fourth session (EA.4/L.11). Nairobi: 13 mar. 2019. Disponível em: https://papersmart.unon.org/resolution/uploads/k1900855.pdf\#overlay-context=node/230. Acesso em: 21 mar. 2019. 